\title{
THE CHANGE OF RELIGIOUS UNDERSTANDING FROM IDEAL-RATIONALITY TO PRAGMATIC-MATERIALISTIC
}

\author{
Ishomuddin \\ Universitas Muhammadiyah Malang \\ Email: ishom_umm@yahoo.com
}

\section{Abstract}

The study is conducted because of the appearance of many new beliefs in Islam, which has had considerable influence for Indonesian Muslims, regardless the fact that the beliefs have mostly been classified as a cult. The purposes of this study are to investigate the new phenomenon in the religious act, involving the change of understanding from ideals-rationality view to pragmatic-materialistic view, and to focus on the phenomenon of the emergence of new faiths in Islamic society in Indonesia. This study is aimed to answer the following questions: (1) What motives lie behind the change of religious understanding from ideals-rationality view to pragmatic-materialistic view in today's Muslim group?; (2) How does the changing process of religious understanding occur in the Muslim group?; (3) Why do religious people today tend to be pragmatic-materialistic oriented and leave the religious teachings that have been previously understood? Qualitative approach is used to examine the research questions. The research result shows that there are three kinds of typology of Muslim groups which experience a shift in religious understanding from ideality-rationality belief to pragmatic-materialistic belief. This happens because there is a gap between the quality of faith and the desire to become instantly rich.

Penelitian ini dilakukan untuk mendeskripsikan dan memahami gejala new act dalam beragama yaitu fenomena pergeseran pemahaman spiritual dari idealitas-rasionalitas ke pragmatis-materialistis dalam beragama. Penelitian ini difokuskan pada fenomena munculnya kelompok-kelompok atau aliran-aliran 
baru dalam masyarakat Islam di Indonesia. Secara rinci penelitian ini adalah untuk menjawab pertanyaan-pertanyan berikut ini. Apa yang melatarbelakangi adanya perubahan pemahaman agama dari idealitas-rasionalitas ke pragmatismaterialistis dalam beragama masyarakat sekarang ini? Bagaimana proses perubahan keberagamaan itu terjadi pada masyarakat Islam? Mengapa umat beragama sekarang ini cenderung kepada pemahaman agama secara pragmatismaterialistis sehingga kehilangan orientasi dan meninggalkan ajaran-ajaran agama yang telah dipahami sebelumnya? Penelitian ini menggunakan pendekatan kualitatif. Berdasarkan analisis data terdapat tiga macam tipologi kelompok muslim yang mengalami pergeseran pemahaman agama dari idealitas-rasionalitas ke pragmatis-materialistis. Hal ini terjadi karena adanya kesenjangan antara kualitas keimanan dengan keinginan untuk menjadi kaya secara instan.

Keywords: shift; new act; ideal-rationality belief; pragmatic-materialistic belief; religious faith; Islam

\section{Introduction}

In Indonesian Islamic Encyclopedia, the word religion comes from the Sanskrit word, which originally came to Indonesia as the name of Hindu Shiva scripture classes (their holy book is called religion). Later, the word was widely known in Indonesian society. However, in its use now, it is not referring to the holy book. It is understood as a typical name for a particular belief in life ackowledged by the society, as the words dharma (also from Sanskrit), din (from Arabic), and religion (Latin) understood.

Religion is the feature of human social life that is universal in the sense that all of society has ways of thinking and patterns of behavior that qualify as «religious». Many things in the religion are known as the superstructure: religion consists of the types of symbols, images, beliefs, and specific values of which humans interpret their existence. However, since religion also contains ritual components, most religions are also classified as the social structure.

Social researchers face many difficulties in formulating a proper religion. The main problem in achieving a precise definition is in determining where the boundaries of the symptoms should be placed. As stated by Robertson (1988), there are two main types of definitions of religion that have been proposed by social researchers; inclusive and exclusive. Inclusive formulate definition of religion in the broadest possible sense says that every system of beliefs and rituals are infused with the "holiness» or that is oriented to the «eternal human suffering». Those who love the inclusive view generally view 
religion not only as theistic systems which are organized around the concept of supernatural strength, but also a variety of non theistic belief systems like communism, nationalism, or humanism. Instead, exclusive definition limits the term religion on belief systems that postulate the existence of the creature, power, or supernatural powers. Belief systems such as communism or humanism, which do not include a supernatural world, are automatically excluded, although it may be accepted that the non-theistic belief systems have similar elements to the religious systems.

One of the provocative sociological analyses of religion is conducted by a leading French sociologist Durkheim early this century. In his book, The Elementary Forms of Religious Life (1947), Durkheim seeks to understand the social role of religion by studying the shapes of the simplest or the most elementary form of religion. In his book, he analyzes the religious rituals of totemic Arunta, a community of hunter-gatherers in Australia. Durkheim has many years of ethnographic knowledge about that society.

A religion is a belief system that is unified by a practice concerned with things that are holy, and allow practices which unite a moral community called a Church, all of those are closely related to one another (Durkheim, 1947). "I formulated the religion as a set of forms and symbolic actions, that connect people to the final conditions of existence" (Bellah, 1967; 1974). Thus, religion can be defined as a system of beliefs and practices in which a group of people struggling with the problems until the end of human life (Yinger, 1970).

Empirical studies indicate a close conformity between the evolution of religion and the evolution of political economy. A study by Swanson (1991) showed that religions generally develop supernatural sanctions for morality when societies become stratified. In calling the religion as the "opium of society", Marx (1999) argues that religion serves as a way to relieve the suffering generated by the exploitation and oppression. He also argues that religion is a deeply conservative political force. Weber (1930) has a similar view. He notes that the function of religion is for groups that have privileges and that religion serves as a means to compensate for the mismatch of their situation. There are many historical and sociological evidents that support the basic affirmation of Marx and Weber.

However, in many cases, Marxıs theses are considered inappropriate. Religion is sometimes thought as a radical force, rather than a conservative force. This is clearly demonstrated by their movements or millenarian revitalization throughout the world and throughout human history. The movements are 
radical social movements that combine the themes of religious and political acts in an effort to change the world's fundamental ways. Although many revitalization movements imply the limitation to Marxıs view, in another sense, it supports movements for the movements to justify the notion of Marx that religion is the "heart of the world pitiless".

The first definition of religion mentioned above is well known and has been cited repeatedly by many sociologists. For Durkheim (1947), religion's important characteristic is that religion is oriented with something that was formulated by humans as holy/sacred object reference, which was appreciated, and even devastating. The world is sharply opposed to the profane world, or world of ordinary and everyday existence. The second and third definition cited above emphasize that religion is, above all, oriented with «the end of suffering» (ultimate concerns) of mankind. Any concerns related to the end, according to Yinger (1970), are thought as the essence of the religion, that is related to the fact of death; the need to cope with frustration, suffering and tragedy; the need to curb the hostility and self-centered; and the need to «take care of the power upon us, endangering our lives, our health, and the continuation of life and the smooth working groups in which humans live, and are powered by heir empirical knowledge that cannot be adequately handled.

\section{Reciprocal Influence between Religion and Society}

The interplay between religion and society is the focus of attention of the sociology of religion studies. An expert on the sociology of religion, Vernon, in his Sociology of Religion (1962) focuses his attention on these issues. More than half of the contents of his book describe the interplay between religion and government, religion and education, religion and economic factors, religion and marriage, and religion and social stratification. On the other hand, Smith's Religion and Political Development, An Analytical Study (1970), studies the relation of religion to politics. The similar study is also found on the writings of other sociologists, although only focused on certain aspects. Weber, for example, in the world of sociology of religion is known as one of the leading figures and a pioneer in the social science discipline, alongside with Durkheim. He focused his research on the influence of religion on economic behavior. The result of his study was written in two books, The Protestant Ethic and the Spirit of Capitalism and The Sociology of Religion. The same problem was also analyzed by Tawney, in his book Religion and the Rise of Capitalism (1926). 
It seems that not all sociologists agree with Weber's research results. Mixed reactions, criticism and condemnation, appeared in addition to the support to his books. Criticism and condemnation of the weaknesses of Weber's study of sociology were reflected in two books, namely Religion, Work Ethic and Economic Development, edited by Abdullah (1982) and Weber and Islam, a Critical Study, written by Turner (1994).

It is possible that there is a link between the progress that has been achieved by a society with their religion. There is also a reciprocal relationship between a religion and a state, as well as the extent of the possible influence of the emergence of religious teachings and the Southeast Asian nations. These areas have been attempted to be studied by sociologists. The results of their study were published in several books, such as The Progress and Religion (Dawson, 1960), Religion and the State (Greene, 1941), and Religion and Nationalism in South East Asia (Von der Mehden, 1968).

Regarding the sociological studies mentioned above, it can be concluded that there are four beliefs known among sociologists of religion, namely the classical belief, positivism belief, conflict theory and functionalism beliefs, and the functionalism belief, which is the most dominant of all. Considering the conclusion of the patterned beliefs, it does not mean that there is no study of the sociology of religion with other patterned belief. For an example, The Social Structure of Islam (Levy, 1971), that attemps to outline the sociology of social structure consisting in an Islamic society.

There is one more work of the sociology of religion suggested for this study. The book, written by Ibn Khaldun (a scientist and a Muslim statesman, who lived in the late 14th century AD), has a distinctive pattern, which is rather different from other works mentioned previously. The book contained Al-Preamble, which is the introduction of his monumental work, entitled Kitab al-Ibrar, wa Diwan al-mubtadawal Khabar, fi Ayyamil Arabi wal Ajamiwal Barbar, wa man Asroruhum min Dzawi al-Sultani al-Akbar.

Based on the researcher's observation, although Khaldun's work is basically used as the basis assessment of the religious community, in this caseas the general foundation of Islamic sociological studies of religion-but not all parts of his writing is based on the results of his field studies. In addition, his works were equipped and combined with his philosophical thoughts and used a historical approach. Also, in certain aspects, the starting point of his thinking was taken from the normative teachings of religion, for example the Qur'an. Thus, Khaldun's articles cannot be classified as "pure" sociology of 
religion, but semi philosophy, namely social philosophy. They may also be called semi social theology, in the sense that he used the concept and the Islamic view of society and the state. Considering such realities, Sulaiman (1987), called Khaldun's works as "the philosophy of Ibn Khaldun Sociology". Issawi (1950), also wrote about the thoughts of Ibn Khaldun in his book An Arabic Philosophy of History.

Khaldun's work has contributed valuable ideas to the area of Sociology of Religion. Recognition of the services of Khaldun in sociology, was not only given by Muslim researchers, but also by Western researchers, such as Abraham (1977) in his book Origin and Growth of Sociology. In his book, he included Ibn Khaldun as a figure of sociology medieval.

\section{Religion and its Influence in the Life}

Geertz (1963: 176) formulates a religion in the references of sociology of religion,"Religion is a system of symbols that is done to create a mood and a strong motivation, completely thorough and longer work in human beings to formulate the concept of a general nature about everything (existence) and by wrapping the conception that the atmosphere of certain factual mood and motivation feels truly realistic".

Nottingham (1990), a sociologist of religion, argues that religion is not something that can be understood through the definition, but rather through a description. There is no single definition of religion that is really satisfying. According to Nottingham (1990), religion is a symptom that is so often «found everywhere», and religion with regard to human efforts to fathom the depth of the meaning of existence of himself and the universe. Besides, religion can evoke the most perfect inner happiness, and also feelings of fear and horror. Although attention is drawn to the existence of a world that cannot be seen (the hereafter), yet it involves itself in matters of everyday life in the world.

Religion as a form of human belief in supernatural something that is appeared as if the man is accompanying the broad scope of his life. Religion has a value to human beings as individual persons and in relation to society (Ishomuddin, 1996). Besides, religion is also known to have impact to everyday life. Thus, psychologically, religion can serve as a motive for the intrinsic and extrinsic motives. The religious beliefs are considered to have the awesome power, which is difficult to surpass by non-religious beliefs, both doctrine and ideology that are profane. Religion is unique, which is hard to be defined appropriately and satisfactorily. 
With the rapid needs of the real world as well as the desire to obtain a position, to be rich instantly, and to have economic condition that is more stable, the orientation of understanding the religion in the modern age nowadays is no longer based on the things that are still theoretical and abstract as the views proposed by Durkheim, Bella and Yinger. In fact, there are many Muslims who are trying to acquire wealth in a way that is sometimes on the contrary to the teachings of the religion itself.

The urge to live in a modern way makes some Muslims try to find ways to meet their needs quickly and profitably. This phenomenon is captured by a person or a group of people as a possible way to set up a hermitage that leads to a new sect in Islam by promising something that requires some followers.

Some cases have appeared in various regions in Indonesia and from various religious groups generally derived from Islam. These groups have offered a «doubling the money» system in ways that are not rational. Practices of this kind in the modern world always get a vast response from the Muslim groups, especially from those who face many difficulties in life. Clearly, by joining these notorious groups, most Muslims have lost their idealism. These people have even left their religious faith behind to switch with certain character or belief suggested by their new leader.

From the appearrance of the above phenomenon, a few questions should be answered. What were the motives behind the change of ideal-rationality belief into religious pragmatic-materialistic belief in todayss Muslim group? How does the process of religious change occur in the Muslim group? Why Muslims today tend to bring pragmatic and materialistic beliefs in Islam so that they leave the teachings of Islam that have been previously understood?

\section{Research Method}

\section{Design}

The research approach used in this study is descriptive qualitative, in which this study describes the phenomena observed and examined using methods of data collection, observation and in-depth interviews, and documentation. In general, a qualitative research is a research that focuses more on the process than the result. To obtain the results, the study was started from the basic assumptions of the observed phenomenon supported by studies of relevant literature. The collection of data using the techniques mentioned above is then 
presented, reduced, verified, and then drawn into conclusions based on the propositions built concurrently and simultaneously in the research process.

\section{Participants}

The participants of this research are the followers of the new Muslim group selected purposively. To get the data in the form of scientific views related to the phenomenon under study, several Islamic scholars and clerics are included as the participants of the study. For the followers of the new Muslim group, the collected data was taken from religious understanding and reasons for joining the new group. For the scholars and clerics of Islam, the researcher collected data in the form of both theoretical and practical views on the emergence of the new beliefs.

After collecting the data, the researcher analyzed the data through a heuristic process as developed by Leech. With this process, the data is interpreted by using propositions that exist in the minds of researcher and supported by field notes, documentation and interviews. Propositions were tested based on the availability of the data. If the first assumption is not proven, new propositions should be created from the data.

\section{Data Analysis}

This research is done with a few steps in accordance with the order of field work (see chart 2) as follows. First, pay attention on the cases related to the emergence of a new belief, which is done by using the observation method. The second phase, conceptualization and categorization changes in Islamic thought are observed. To obtain data on this, in-depth interview is conducted. The third stage is compiling the research findings, which is done by using qualitative descriptive analysis. The fourth stage is preparing and making the research report. The above process can be described in the following chart. 


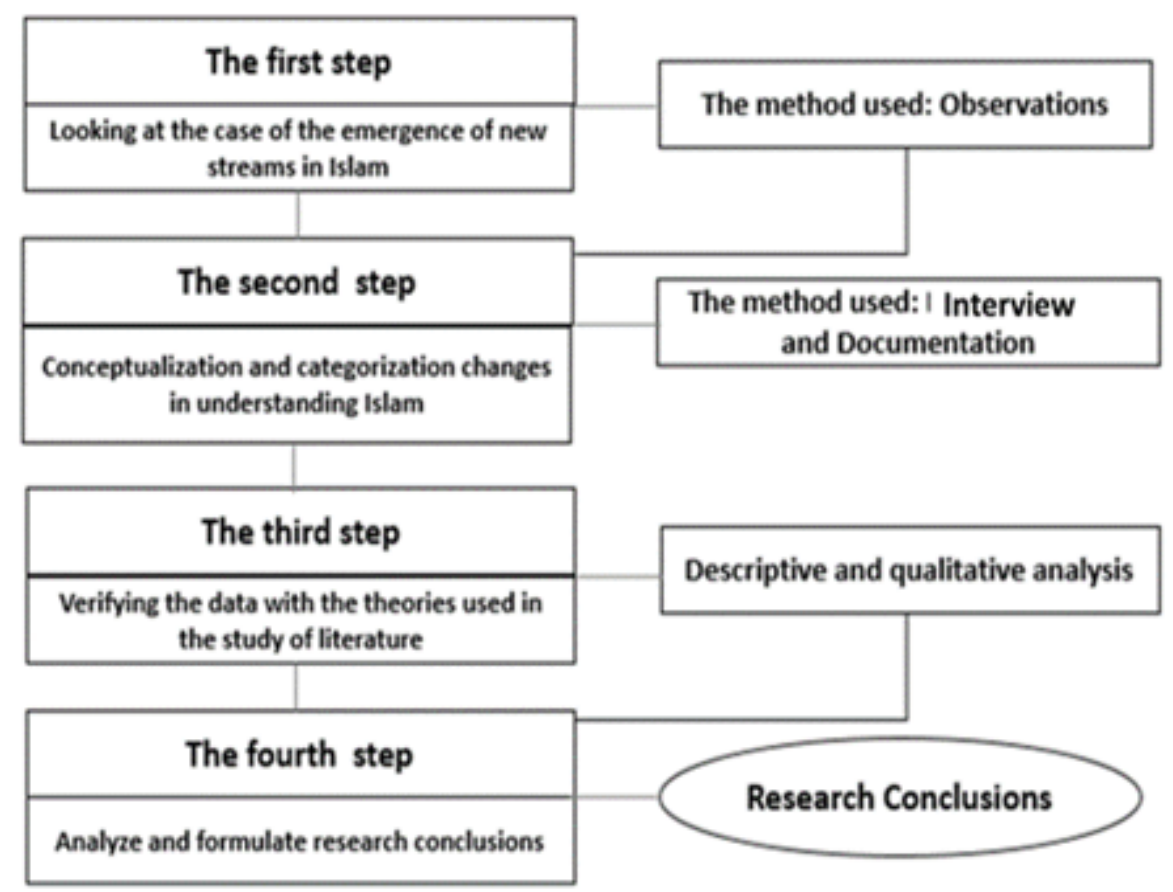

Figure 1. Research Procedire

\section{Findings}

The primary data of this research is the interviews taken from the research participants. After doing field research and interviewing the research subjects, the substance of all the data in the form of epic data is classified into three types. First, when the informants were asked about their reasons for joining the new Islamic sects, they had the following arguments. They said that as Muslims, they were obedient to the teachings of Islam and did so in accordance with the orders and prohibitions. However, in carrying out the teachings of Islam, some of them might have real-life problems, such as shortages or economic hardship in life. Sometimes, the economic condition was affluent; however, some of them said that they had the desire to get more than they have already owned. Thus, when they heard that there was a new faith of Islam promising about the doubling money program, they were very keen on joining the group, although they had to stay far away from home and join all activities carrying out by the group. 
On the other hand, other participants revealed that they originally came from family with difficult economic conditions. When they had information about the new Islamic group which promised the doubling money program, they were interested in joining the group and voluntarily giving their capital money. They expected their money to be doubled in number quickly so that they could immediately return to the family and make their family economic condition better than before. In reality, it was not as easy as what they had imagined. Until now they have not received their money back.

Furthermore, the participant group argued that the reason of their participation in the new group is because they wanted to be richer than before. This group cotained people who have had a lot of money. They usually used their money to start a business which required minimun business activities. They were eager to join the new Islamic group that promises 100-fold multiplication of their money without thinking rationally of the possible consequences of their action. They were attracted by the campaign conducted by the leaders and supporters of the group, so that they are assured that the group has taught a truthful belief of Islam.

The data obtained from the intellectuals mentioned that in the era of modernization and globalization, challenges of life are significantly increased for small communities, especially the lower class Muslim groups. The demands of life in the modern era had caused the life of this class group difficult, especially with the low wages they got from their labor work. The money they earned from work would not be enough for them to access and enjoy the modern life. On a micro level, many households lost stability and underwent domestic upheavals because of the domestic economic factors. In turn, the majority of these people would get divorce or look for other ways to solve their financial problems or to increase the families' income in a way that would not be allowed by Islam. In these conditions, religion was no longer considered as an important part of their lives. Furthermore, the people who are divorced would generally feel like a stranger in his/her own home. Thus, he/she would find a place or a patron who is considered more calming or promise anything.

In these circumstances there was a person or a group of people who set up a wide range of new faith in religion (Islam). These individuals or groups approached any Muslims who had lost faith in their religion. In general, these new Islamic groups were promising comfort or ease of living. They even had a doctrine basis religious teaching that was different from what other mainstream Islamic organisations in Indonesia have had. They also 
had a base in the form of huts, houses, or hermitage. The followers of these groups usually felt more comfortable living in the group's neighborhood or in their own houses. This condition, in the sociology of religion, is called «dislocation» or «disorientation». The groups' followers were usually looking for a new place to live, although actually it is more comfortable and better to live in their own houses. They felt safer to live in the new place, even though the place was like a prison. Why does this happen? It happened because they experienced a stage of "disorientation" of religion or sect. The groups' followers have abandoned their ideal-rational view since they joined the new organization. They thought that the orientation of the new religious group is more promising to solve their problems associated with economic needs. They also thought that the new organization could help them solving the problems in an instant way. Nowadays, the religious "disorientation" is experienced globally by the followers of the new Islamic faith.

\section{Discussion}

The data above can be analyzed descriptively. The cause of this change is essentially the same: life orientation and economic needs. The three participant groups above show different reasons for joining the new organization. Nevertheless, those distinctive reasons ultimately lead to the same destination. Further classification about the groups' participants are explained below.

The first group of participants can be classified into followers who have established economic condition, but ordeal more pleasure in their lives. Actually, in normal condition, these people can live with employment income that has been earned each month. They can actually be categorized as the Islamic ideal and the rational group in terms of facing their lives. Yet, they think that what they have earned and achieved are not enough. In addition, they want to become rich instantly. Therefore, they are searching for a new religious organization that can double their properties or money, or at least provide strategies to become rich quickly.

The second group consists of people who have problems with their financial condition. They are looking for the other way out to solve their financial problem, but the way out is still considered permissible by their religion. They are going to the shaman or new streams in Islam that are considered reliable to support the economy of their family. They are willingly joining the group that promises to double their money or provide strategies for a pleasant life in an instant way.

el Harakah Jurnal Budaya Islam Vol. 19 No.2 Tahun 2017 
The third group contains participants who are already wealthy, but they want to be richer than before. This third Muslim group has excessed property, but they want to double their wealth without any effort to do so. They do not realize that the new stream of Islam is lying to them, although technically the stream is justified by the teachings of Islam. The third group is the strongest Islamist group, using the excuse that they have experienced shifting orientation from religious understanding to the original idealistic-rational. They teach everything to their followers, including the thought that the rich and the poor are in Godss provision and the orientation of understanding pragmatic and materialistic views that make the followers getting rich quickly or doubling their affluent property in an instant way. For the followers, all of these teachings are still considered as Islamic way or not out of the teachings of Islam. Therefore, it is considered permissible in Islam.

The issue of religion is a fundamental issue because it involves the belief that is associated with conscience. It is not easy to change those beliefs, even though the followers are in difficult position and face the great challenges in their lives. In fact, many people who join the sect have changed their life orientation and even violated the moral principles of their religion. This phenomenon has long been studied by Fromm. According to him, judging from the function and role of religion in giving effect to an individual, either in the form of a value system, motivation, or guidance of life, the most important influence was as a shaper of conscience (1959). Conscience, according to Fromm, is a call back to the man himself (1959). Shaftesbury (1999) assumes conscience as a moral sense in man, a sense of right and wrong, an emotional reaction based on the fact that the human mind is centered to himself in arranging his harmony with the cosmic order. Arguably, scholastic philosophy (religion) firmly told that the conscience is the awareness of moral principles.

This phenomenon illustrates that there is a level of understanding in the body of the Muslims. In addition, the lowest level of understanding needs to be maintained or supported by a good environment. Islamist groups, as the most vulnerable groups in Islam, do not react well to the influences from the environment. This is in line with what was said by Fromm (1959) that a human being has some potential factors to give directions in human life. Those factors are; (1) instinctive, (2) sensory, (3) reasoning, and (4) religion. Through this approach, the religion has become a potential disposition inborn. The environmental influences of a person give guidance to human's potential factor. Thus, if the potential factor of nature that can be developed 
is in line with the environmental influences, there will be harmony in the man's life. Conversely, if the potential is developed in a condition opposed to the environmental conditions, the man's life will be imbalanced.

With this approach, the influence of religion in the life of the individual is to give inner stability, a sense of happiness, a sense of protection, a sense of success and satisfaction. The more positive feelings will be driven to the life of the human being's. Religion in the life of the individuals is aimed to give additional motivation, ethical values, as well as the hope for the future. Religion also has the effect of motivating or encouraging people to do an activity, due to actions undertaken against a background of religious beliefs assessed as having elements of chastity and obedience. This linkage will have no effect on a person to do something. While religion which is considered as ethical value in doing one's actions will be bound by the provisions of which activities are allowed or not not allowed according to the teachings of the individual's religion. In this case, religion gives hope for the culprit. One who performs religious orders generally seeks for the forgiveness or compassion from an occult (God/supernatural).

From the data above, the three typologies of Muslim groups and their motives of joining the new streams of Islam in recent years can be described in the following chart.

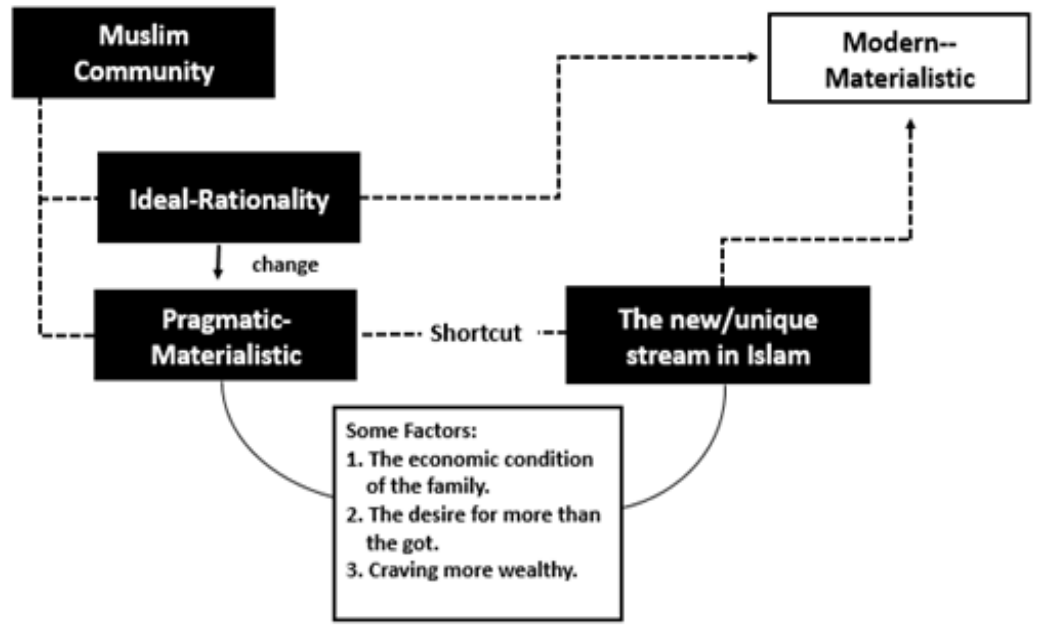

Figure 2. Changes in Understand of Islamic Community in Respone Modern Life 


\section{Conclusion}

Based on the data analysis above, it can be concluded that there are three kinds of typology of Muslim groups which experienced changes in their belief from the ideal-rationality toward the pragmatic-materialistic. Each typology can be briefly explained as follows. First category contains families whose lives were not in harmony because they lacked finances or possessions. They joined the new Islamic organization that had a goal to double money or possessions instantly. The people in this group thought that the organization's aim is still in the realm of Islam. Second, the group consisted of harmonious and financially established families. They thought that the wealth they owned were not enough for them. Therefore, they were looking for new beliefs of Islam that were able to double their money or properties.

Third, the group contained families that were quite wealthy, but they still wanted to be richer than before. These families were influenced by a group or organization that promised to multiply their money. Without thinking logically, they were interested to join the new organization and they deposited enough money, hoping that the money would be returned double folds.

Sociologists of religion considered all of these actions as a symptom of the emergence of «new act», for example communities, particularly Muslim groups which experienced disorientation and dislocation in life so that they consciously or unconsciously changed their understanding of religion (Islam) from ideal-rationalistic to pragmatic-materialistic.

\section{References}

Abdullah, T. (1982). Agama, etos kerja dan perkembangan ekonomi. LP3ES.

Abraham, J. H. (1977). Origins and growth of sociology. Harmondsworth, UK: Penguin.

Bellah, R. N. (1967). Civil religion in America. Daedalus, 96(1), 1-21.

Bellah, R. N. (1976). New religious consciousness and the crisis in modernity. The new religious consciousness, 333-352.

Dawson, C. (1930). Progress and religion: an historical enquiry. The Sociological Review, 22(1), 52-65.

Dhavamony, M. (1995). Fenomenologi agama. Yogyakarta: Kanisius. 
D Hendropuspito, O. C. (1983). Sosiologi agama. Yogyakarta: Kanisius.

Durkheim, E., \& Swain, J. W. (2008). The elementary forms of the religious life. Courier Corporation.

Esposito, J. L. (1985). Islam dan perubahan sosial-politik di negara sedang berkembang. Yogyakarta: PLP2M.

Fromm, E. (1959). Sigmund Freud's mission: an analysis of his personality and influence. Peter Smith Publication.

Geertz, C. (1963). Agricultural involution: the process of ecological change in Indonesia. Berkeley: University of California Press.

Greene, E. B. (1941). Religion and the state: the making and testing of an American tradition. Ams Press Inc.

Ishomuddin. (1996). Pergeseran nilai pemahaman keagamaan dan perubahan sosial di pedesaan, Jumal Ulumuddin, Fakultas Agama Islam Muhammadiyah Malang.

Issawi, C. (1950). An Arab philosophy of history: selections from the prolegomena of Ibn Khaldun of Tunis (p. 190). London: John Murray.

Khaldun, I. Kitab al-Ibrar, wa Diwan al-Mubtadawal Khabar, fi Ayyamil Arabi wal Ajami wal Barbar, wa man Asroruhum min Dzawi al-Sultani al-Akbar

Leech, N. L. (2007). Sampling designs in qualitative research: making the sampling process more public. Qualitative Report.

Levy, R. (1971). The social structure of Islam (Vol. 182). CUP Archive.

Marx, K. (1999). Kajian kritis das capitals. Teplok.

Nottingham, K. E. (1990). Agama dan masyarakat: suatu pengantar sosiologi agama (Transl. A. M. Narahong). Jakarta: Rajawali.

O'dea, T. F. (1968). The sociology of religion. New Jersey: Prentice-Hall, Inc.

Robertson, R. (1988). Agama dalam analisa dan interpretasi sosiologis. Jakarta: Rajawali.

Sanderson, S. K. (1993). Sosiologi makro: sebuah pendekatan terhadap realitas sosial. (Transl. F. Widjidi \& S Menno). Jakarta: PT Raja Grafindo Persada.

el Harakah Jurnal Budaya Islam Vol. 19 No.2 Tahun 2017 
Shaftesbury, A. A. C., (1999). Characteristics of Men, Manners, Opinions, Times, ed. Lawrence E. Klein Cambridge: Cambridge University Press.

Smith, D. E. (1970). Religion and political development: an analitic study. Boston: Little, Brown.

Sulaiman, F. H. (1987). Pandangan Ibnu Khaldun tentang pendidikan. (Transl. H. N. Ali). Diponegoro.

Swarsono \& Alvin Y. S. (1991). Perubahan sosial dan pembangunan di Indonesia. Jakarta: LP3ES.

Tawney, R. H. (1926). Religion and the rise of capitalism (Vol. 23). Transaction publishers.

Turner, B. S. (1994). Sosiologi Islam: suatu telaah analitis atas tesa sosiologi Weber. Jakarta: Rajawali.

Vernon, G. M. (1962). Sociology of religion. New York: McGraw Hill Book Coy.

Von der Mehden, F. R. (1963). Religion and nationalism in Southeast Asia: Burma, Indonesia, the Philippines. University of Wisconsin Press.

Wallace, A. (1966). Religion: an Anthropological View. New York: Random House.

Weber, M. (1930). The Protestant ethic and the spirit of capitalism. (Transl. T. Parsons). London: George Allen and Unwin.

Yinger, J. M. (1970). The scientific study of religion. New York: Macmillan. 